\title{
An Examination of the U.S. Airline Policy Regarding Child Restraint Systems
}

\author{
Larry Carstenson and Donald Sluti \\ University of Nebraska at Kearney \\ and \\ Jacqueline Luedtke \\ Utah State University
}

\begin{abstract}
This study examined the policy of the U.S. commercial air carriers regarding the use of infant restraint systems on aircraft. The study determined whether airline management and airline personnel understand that policy and whether that policy is effectively communicated to the traveling public. This study investigated the effectiveness of communication between airline management and airline personnel regarding airline policy for the carriage of infants in commercial airplanes. The results of this survey were analyzed in order to determine if any recommendations could be made to the airlines regarding child restraint systems on commercial aircraft.
\end{abstract}

\section{Introduction}

As much as any major aviation accident, the air disaster involving United Airlines Flight 232 in Sioux City, lowa, in 1989 emphasized the plight of infant travelers in commercial air travel. Flight 232 was somewhat unusual in that the flight crew and cabin attendants had ample time to prepare for an emergency landing--almost 45 minutes according to the NTSB report submitted after hearings on the accident (NTSB, 1990, p. 21-23). There were four passengers listed with children under the age of two years old on Flight 232. The flight attendants had done everything exactly as they were trained; they had instructed the parents with small infants to place the children on the floor between the legs of the parents. Because the plane cartwheeled upon impact, that method did not work and infant deaths resulted (Child Restraint Systems, 1990).

Current Federal Aviation Regulations (FARs) require everything in an aircraft to be strapped down for takeoff and landing--everything, that is, except infants less than two years of age (Title 14, 1995, Section 121.311). The FARs specify that everyone on board a commercial aircraft ". . shall occupy an approved seat or berth with a separate safety belt properly secured about him or her during movement on the surface, takeoff, and landing" (Title 14,1995 , Section 121.311b). The regulations continue: "Notwithstanding the preceding requirements, a child may: (1) be held by an adult who is occupying an approved seat or berth if that child has not reached his or her second birthday . . ."

The Federal Aviation Administration (FAA) emphasizes the importance of child restraint systems in the Child Passenger Safety Resource Manual which states, "The Federal Aviation Administration recommends that young children ride in child safety seats during air travel. Child seats will not only enhance the child's safety in the event of a crash but will also protect the child from injury during in-flight turbulence and rough landings" (U.S. DOT, 1993). In the event of an airplane crash, or even in cases of severe turbulence, that unsecured child 
may not only be injured but may actually become a human projectile, capable of causing as much damage as an unsecured twenty-pound briefcase.

As long as the government continues to grant to parents traveling with infants the option to either use infant restraint systems or to place the infants on their laps (Title 14, 1995, Section 121.311c), the traveling public and the airlines will be confused about what must be done to insure the safety of those infants. In this study the researchers wanted to determine the policy and practice of the major U.S. commercial air carriers (American, America West, Continental, Delta, Northwest, Southwest, Trans-World Airlines, United and USAir) regarding the use of infant restraint systems. Does management of each airline know what that policy is? Do management personnel communicate with airline employees when policies are implemented, maintained and enforced or are those policies, by default, set by individual airline reservation agents or flight attendants at the time they are dealing with the traveling public? In other words, does confusion exist within the airline industry with regard to the carriage of infants on commercial air carriers?

\section{Purpose of Study}

The researchers initiated this study to determine if a lack of communication existed between management of the major United States air carriers and their airline reservation agents regarding airline policy for the carriage of infants in airplanes. It was the perception of the researchers that such a lack of communication could cause confusion among commercial air travelers which might result in inconvenience and possibly even danger to infants who are engaged in commercial airline travel.

The researchers first wanted to determine the policy of airline management regarding the carriage of infants on commercial airliners. Second, the researchers wanted to determine, through the use of surveys, whether that policy was effectively communicated by airline management to airline reservations agents. Third, the researchers wanted to ascertain whether the airline policy regarding infant restraint systems is being effectively communicated to the traveling public. Finally, the researchers wanted to see if any basis exists for advocating a national policy change.

\section{Background Literature}

Prior to the issuance of a 1982 order by the FAA (Technical Standard Order C100), the use of passenger-furnished child restraints was not allowed during the takeoff or landing of an airplane (Gowdy \& DeWeese, 1994). However, since 1982, the FAA has authorized the use of child restraint devices on airplanes for the carriage of children. The current regulations (Title 14, 1995, Section 121.311(c)) read, in part, as follows:

No certificate holder may prohibit a child, if requested by the child's parent, guardian, or designated attendant, from occupying a child restraint system furnished by the child's parent, guardian, or designated attendant, provided the child holds a ticket for an approved seat or berth, or such seat or berth is otherwise made available by the certificate holder for the child's use, and the requirements contained in paragraphs (b)(2)(i) through (b)(2)(iii) of this section are met. This section does not prohibit the certificate holder from providing child restraint systems or, consistent with safe operating practices, determining the most appropriate passenger seat location for the child restraint system. 
Two questions permeate the body of research and discussion regarding the use of infant restraint systems in commercial air travel. The first is that if the use of such infant restraint systems were made mandatory, would the increased costs (which are certain to result from the mandating of use of infant restraint systems) compel those members of the public traveling by air with small children to select alternate, and potentially more dangerous, methods of travel? The second question is perhaps the more difficult one to understand, or at least accept, from the perspective of a parent of a small child. Would the reduced number of expected infant deaths resulting over a ten-year period by mandating the use of infant restraint systems be cost effective enough to warrant the major expense which would undoubtedly be incurred as a result of such a mandate?

According to Consumer Reports, the act of balancing the financial interests of the commercial air operators against the serious questions of public safety "can create some strange calculus" (FAA, 1995). This article refers to a government study which, using a costbenefit approach, places a value of $\$ 2.6$ million on a human life. However, according to the FAA, the cost of mandating the use of infant restraint systems would exceed $\$ 1$ billion over the next ten years. This causes the FAA to resist new rules mandating the use of child restraint seats in commercial airliners. According to Consumers Research Magazine, the number of injuries or fatalities that could be prevented by infant restraint seats on airplanes is minimal:

the FAA estimates use of seats would have prevented one infant fatality, one serious injury, and between two and five minor injuries if child safety seats had been used between 1978 and 1990. The NTSB disputes these numbers but does not, according to its congressional testimony, indicate substantial differences. (Spencer, 1994)

Gowdy and DeWeese evaluated the performance of several different child restraint systems including the use of adult lap belts (Gowdy \& DeWeese, 1994). They concluded that all forms of child-restraint devices, including the normal adult lap belt (which was being tested by using an anthropomorphic test dummy assumed to be at least 33 pounds in weight), could have some potentially serious consequences for the two-year-old infant weighing less than 33 pounds who is involved in commercial air travel. Although the use of a normal lap belt would be preferred to holding the child on the lap of the parent, the normal lap belt would be marginal, at best, if the child was too small to be accommodated properly by the lap belt.

What was even more interesting is the conclusion by Gowdy and DeWeese that the use of child restraint systems which satisfy the performance standards of Federal Motor Vehicle Safety Standard 213 may not work well in commercial airliners because an entirely different set of forces is imposed on the restraint system when used in an aircraft. Gowdy and DeWeese point out that airplane seats belts differ from automobiles in anchor point geometry, tension adjustment, and buckle hardware. Also, the consequences of seat back break over on airplane passenger seats, combined with aft row occupant impact on the seat back, were not considered in designing the infant restraint systems for use in automobiles.

The expectation of equivalent protection for children restrained in certain types of CRDs (child restraint devices) traveling by automobile cannot be met in an airplane seat .... In fact, these tests demonstrated some types of CRDs should not be recommended for use in airplane passenger seats . . . The main reason is that CRDs are designed to meet an automotive requirement, FMVSS-213, and do not necessarily adapt properly to an airplane seat. (Gowdy \& DeWeese, 1994, p. 27) 
Insignificant in part because of the research study by Gowdy and DeWeese, the FAA on June 4, 1996 issued a final rule (Federal Aviation Administration, 1996) amending the Federal Aviation Regulations. This amendment withdraws FAA approval for the use of booster seats and vest and harness type child restraint systems in aircraft. The prohibition applies when the aircraft is taking off, landing, or moving about the surface. The prohibition does not apply in flight. The FAA continues to allow infants on board aircraft to be held on the laps of parents during any phase of the flight.

There presently exist two different schools of thought regarding the mandatory use of restraint systems for infants under the age of two years. The FAA says it believes in education, not regulation, because forcing parents to buy an extra ticket and borrow a special seat for their children would result in families being forced to drive instead of fly. That would be riskier, according to the FAA (Field, 1996). Some members of Congress want to mandate the use of infant restraint systems on commercial aircraft. Congressman Lightfoot, 3rd District, lowa, reintroduced legislation to amend Title 49, United States Code, to require the use of child safety restraint systems approved by the Secretary of Transportation on commercial aircraft. (Congress, 1995) Hearings on this bill were held in August, 1996 (Lightfoot, 1996). It does not appear that the chances of passage of this bill by the 104th Congress are any better than they were when the bill was first introduced several years ago. According to the LEXIS bill forecast (1995 Information For Public Affairs, Inc. 1996), the odds that H.R. 1309 will pass are given as no better than five percent.

\section{Nature of the Problem}

The parent of every child traveling in commercial aviation today wants to do absolutely everything possible to protect that child in the highly unlikely event of an airplane crash. The problem is that the parents do not know what specifically must be done to insure the survival of that child when faced with a disaster such as occurred in Sioux City with Flight 232. Consider the testimony of Jan Brown, a flight attendant serving on United Flight 232, when she testified before the House Aviation Subcommittee in support of a bill to require the use of child safety restraint systems on commercial aircraft. During her testimony, Ms. Brown described what had happened immediately after the crash landing at the Sioux City Airport after she evacuated the passengers and exited the airplane.

Making my way through the corn field, the first passenger I met was Sylvia Tsao, who was headed back towards the burning plane. She told me that she had to return to the plane to find her infant son. I restrained her from proceeding and told her someone would find her son. She turned to me and blurted out that I had told her to place her son on the floor and hold him. She had done that and now he was missing. I was overcome with the knowledge that I would live with those words for the rest of my life. Evan Tsao died in the crash. (Child Restraint Systems, 1990)

Each of the nine airlines appears to have a different policy regarding the carriage of infants in commercial air travel and the proper protection of that child in the event of an emergency. Most parents know what to do if they buy an airline ticket for their child. The FARs mandate that the airlines must allow a child seat to be used in air travel as long as that child seat is approved as specified in the regulations and a ticket is purchased for that child (Title 14,1995 , Section 121.311(c)). The parents may not know, however, what to do if they do not purchase a ticket for their infant. 
Mandating the use of infant restraint devices in commercial air travel could potentially solve that problem. However, it is asserted that, if the use of such restraint devices were made mandatory, more children would die. This is assuming that the mandating of the use of such restraint systems would necessitate the charging by the airlines for that extra seat used by the infant, and that extra charge would cause the parent to use an alternative mode of transportation--most likely the automobile (Windle \& Dresner, 1991).

\section{Methodology}

The study investigates the proposition that there may be communication failures between airline management and airline reservations agents with regard to the transmission of airline policy on the carriage of children under two years of age. To do this, a telephone survey was conducted of both the management personnel and of 45 reservations agents (5 from each airline) of the nine major United States air carriers. The survey employed the hypothetical case involving the commercial air travel of a mother traveling alone with her oneyear-old daughter. Interviews determined management policy for each of the airlines and then followed up on management's explanation of that policy by determining what the airline reservation agents tell the parent who travels with an infant less than two years of age.

Data collection considerations led to the selection of the research methodology of this study. The research design progressed as follows. The decision of what data must be collected in order to accomplish the purposes of the study was addressed. Then, the most appropriate method of data collection was considered. Next, the data collection instrument was constructed and reviewed. Following this, the data was collected. Finally, the data was tabulated and interpreted. In this section of the study is contained a brief description of the procedures which were followed.

First, the potential sources of information were determined in several brainstorming sessions among the researchers. After reviewing the literature and becoming familiar with FAA regulations, the researchers concluded that the data necessary for conducting the study would only be available from the airlines themselves. That is, the best source of management policy would be from management and that the best way to determine what reservation agents tell potential customers was to contact the reservation agents themselves.

A telephone survey was selected as most appropriate data collection method for this study. Alreck and Settle (1985) and Simon and Burstein (1985) note that several advantages of gathering data by telephone are: one can contact a widely dispersed group of individuals or sites; no field staff are required, as may be necessary when conducting personal interviews; this method has a relatively low-cost per contact; also, that interviewer bias is more controllable; it is a rapid means of collecting data; and the response rate is much higher than mail surveys. There are two limitations to telephone surveys, relevant to this study, in that questions and the entire interview must be relatively short. In this study, the sources of information are quite widely dispersed. As in many cases, time and funding were strictly limited, which precluded the use of field interviewers.

The researchers required a very high response rate from both management and reservation agents. Therefore, questionnaires were designed to be orally administered during a structured telephone interview with the management of each of the nine airlines and, subsequently, with each of the airlines' reservation agents. The questionnaires were developed using a panel discussion of the researchers, utilizing inputs from a group of experts on the subject, including individuals from collegiate aviation education, airline flight personnel, 
and airline management personnel. The proposed questionnaires (one for management and one for the reservation agents) were then reviewed by an airline reservation agent for appropriateness, understandability and overall validity. The structured telephone interview technique was employed, although airline management and reservations agents were given the opportunity to expand upon their responses, if they so desired. In order to reduce the potential of interviewer bias, a different individual was designated to interview the reservation agents than the individual who spoke with management. To address reliability concerns, it was decided to contact several reservation agents rather than only one individual. The data collection procedure and subsequent analysis assumes that a random, unbiased sample survey accurately represents the results which would exist if the survey were of all of the knowledgeable individuals in the field.

\section{Procedure for Airline Management Data Collection}

Each of the nine major airlines in the United States was contacted at its corporate headquarters by telephone by one of the researchers. The researchers spoke with a management person at each airline who was knowledgeable about the policy and the procedure of that airline concerning the carriage of infants under the age of two on board their aircraft. The researchers were often directed to persons in customer service, in-flight service or customer safety areas of the airline. The decision regarding the contact person with whom the researchers should speak was made by each individual airline and thus could be seen as a potential limitation to the study.

Since the purpose of the study was to determine airline management policy and the effectiveness of the implementation of that management policy by the airline reservation agents, the researchers first conducted the interviews with management personnel of each airline to ascertain that airline's policies. Airline management was informed that subsequent to their interview reservation agents would be contacted. Management was apprised of the general procedure to be followed in the contacts with the reservation agents.

\section{Procedure for Airline Reservation Agent Data Collection}

The telephone survey utilized a questionnaire designed to gather information on the issue of airline policy with regard to the use of child restraint seats and other related topics. The survey was designed for completion in five to ten minutes. To ensure cooperation in providing information, the survey instrument was designed so as to be perceived by the reservation agent as that of a customer seeking travel information. The use of a pseudocustomer helped ensure that responses given by the reservation agents would accurately reflect what the reservation agent would tell an actual customer

The survey was administered by a single individual to five different reservation agents from each of the nine airlines. By gathering responses from more than one individual from each airline, potential bias was reduced and reliability was verified. The survey was administered by a single individual working with the researchers over a period of two weeks during the summer of 1995 . The individual was selected on the basis of education and relevant experience; that is, the person was both an airway science major and a reservation agent for a commuter airline. The interviewer posed as a mother flying with a child for the first time. The interviewer was rehearsed prior to beginning surveying so as to make the presentation as natural sounding as possible. 
In order to avoid potential bias, the time of day when the calls were made were determined by using a random-numbers table. To eliminate the possibility of the same reservation agent being contacted twice, the interviewer noted the name of the agent and was instructed to not proceed with the survey should an agent's name match that given in an earlier interview. A debriefing session conducted by the researchers with the interviewer upon completion of all the surveys verified that the data from each survey did, in fact, come from separate individuals.

Table 1

Results of Interviews with Airline Management

Results of Airline Management Survey

\begin{tabular}{|l|c|c|c|c|c|}
\hline Airline & $\begin{array}{c}\text { Discount } \\
\text { Tickets } \\
\text { Offered }\end{array}$ & $\begin{array}{c}\text { Sit on } \\
\text { Parent's } \\
\text { Lap }\end{array}$ & $\begin{array}{c}\text { Airline } \\
\text { Furnishes } \\
\text { Child Seat }\end{array}$ & $\begin{array}{c}\text { On Parent's } \\
\text { Lap During } \\
\text { Crash } \\
\text { Landing }\end{array}$ & $\begin{array}{c}\text { Child can } \\
\text { Occupy } \\
\text { Vacant Seat }\end{array}$ \\
\hline American & No Answer & No Answer & No Answer & No Answer & No Answer \\
\hline $\begin{array}{l}\text { America } \\
\text { West }\end{array}$ & No & Yes & No & No answer & Yes \\
\hline $\begin{array}{l}\text { Conti- } \\
\text { nental }\end{array}$ & No & Yes & No & Yes & Yes \\
\hline Delta & No & Yes & No & Yes & Yes \\
\hline Northwest & Yes & Yes & No & Yes & No answer \\
\hline Southwest & Yes & Yes & No & No answer & Yes \\
\hline TWA & Yes & Yes & No & No & Yes \\
\hline United & Yes & Yes & No & No & Yes \\
\hline USAir & Yes & Yes & No & No answer & No answer \\
\hline
\end{tabular}

Discussions with management personnel at the nine airlines disclosed a willingness by most of the airlines to discuss their concerns and official attitude toward the carriage of infants on their flights (see Table 1). Most airline management personnel demonstrated knowledge of the FAA labeling policy for the determination of an "approved" seat within the meaning of the FARs. None of the nine airlines provides infant restraint systems for passenger use. All of the 
airlines allow the use of approved passenger-owned infant restraint systems on board their aircraft.

A majority of the airlines with whom the researchers spoke stated that a discounted fare is available for infants traveling with their parents although the method of computing that discount varies. Most of the airlines were not specific regarding the method of determining the cost of an infant's ticket. Some of the airlines determine the cost of an infant's ticket by using a percentage of the high coach fare. However, the "discount" would appear to be an illusory concept because passengers do not normally purchase a high coach fare ticket. Often the least expensive ticket for a child would be to purchase a normal adult fare on an advance purchase plan according to a majority of the airlines.

All airlines surveyed stated that they allow infants under the age of two to sit on the laps of their parents as authorized by the FARs. The use of an adjacent, unoccupied seat is authorized by a majority of the airlines. However, most airlines stated that the parent will not know if the extra seat is available until the plane is boarded.

No airline furnishes its own infant restraint systems for use by the passengers. All passengers must bring their own infant restraint systems on board the aircraft if they desire to use them for their infants. Most of the airlines stated that the seats must have FAA approval in order to be used on the aircraft.

The most significant area of confusion involved the methods used by the various airlines to brace the infants in the event of an emergency. Most of the airlines said that the parents would be advised to hold the infants on their laps during an emergency landing. One of the airlines informed the researchers that the infants should be buckled into the same seats with their parents. Another airline advised placing the infants on the floor between the legs of the parents. However, one airline has the possibility of an emergency landing well planned. That airline informed the researchers that the infants would be wrapped in pillows and blankets and would be belted into empty seats in the event of an anticipated crash landing.

The information provided by the reservation agents is an indicator of whether airline management's policies regarding the issues surveyed are understood by the representatives of the nine airlines and whether these policies are being correctly communicated to the public.

All forty-five agents informed the interviewer that infants under the age of two years are allowed to fly with their parent without charge. Responses to this question indicate a knowledge of management policy on this issue. All forty-five reservation agents indicated that infants who have not purchased a ticket are expected to sit on the laps of their parents.

Airline policy with regard to the placement of infants during emergency situations was miscommunicated in every instance by the forty-five agents. Without fail, the agents informed the interviewer that the parent should belt the infant into the same seat as the parent during an emergency landing (See Table 2). 
Table 2

Results of Interviews with Airline Reservation Agents

\begin{tabular}{|l|c|c|c|c|c|}
\hline Airline & $\begin{array}{c}\text { Discount } \\
\text { Tickets } \\
\text { Offered }\end{array}$ & $\begin{array}{c}\text { Sit on } \\
\text { Parents } \\
\text { Lap }\end{array}$ & $\begin{array}{c}\text { Airline } \\
\text { Furnishes } \\
\text { Child Seat }\end{array}$ & $\begin{array}{c}\text { On Parent's } \\
\text { Lap During } \\
\text { Crash } \\
\text { Landing }\end{array}$ & $\begin{array}{c}\text { Child can } \\
\text { Occupy } \\
\text { Vacant Seat }\end{array}$ \\
\hline American & $*$ & $\begin{array}{c}\text { Yes: } 5 \\
\text { No: } 0\end{array}$ & $\begin{array}{c}\text { Yes: } 0 \\
\text { No: } 5\end{array}$ & $\begin{array}{c}\text { Yes: } 5 \\
\text { No: } 0\end{array}$ & $\begin{array}{c}\text { Yes: } 5 \\
\text { No: } 0\end{array}$ \\
\hline America & $*$ & Yes: 5 & Yes: 0 & Yes: 5 & Yes: 5 \\
West & & No: 0 & No: 5 & No: 0 & No: 0 \\
\hline Conti- & $*$ & Yes: 5 & Yes: 0 & Yes: 5 & Yes: 5 \\
nental & $*$ & No: 0 & No: 5 & No: 0 & No: 0 \\
\hline Delta & $*$ & Yes: 5 & Yes: 0 & Yes: 5 & Yes: 5 \\
\hline Northwest & $*$ & Yes: 5 & Yes: 0 & Yes: 5 & Yes: 5 \\
& & No: 0 & No: 5 & No: 0 & No: 0 \\
\hline Southwest & $*$ & Yes: 5 & Yes: 0 & Yes: 5 & Yes: 5 \\
& & No: 0 & No: 5 & No: 0 & No: 0 \\
\hline TWA & $*$ & Yes: 5 & Yes: 0 & Yes: 5 & Yes: 5 \\
& & No: 0 & No: 5 & No: 0 & No: 0 \\
\hline United & $*$ & Yes: 5 & Yes: 1 & Yes: 5 & Yes: 5 \\
& & No: 0 & No: 4 & No: 0 & No: 0 \\
\hline USAir & $*$ & Yes: 5 & Yes: 0 & Yes: 5 & Yes: 5 \\
& & No: 0 & No: 5 & No: 0 & No: 0 \\
\hline
\end{tabular}

* This question was not answered by any of the reservations agents because the question was: "When I buy my ticket, do I have to buy a ticket for my daughter? If so, does my daughter pay the same rate as I do or is there a discount fare for a one-yearold?" Since all of the reservation agents stated that it was not necessary for the parent to purchase a ticket for the infant, the question regarding the discount was not answered.

Forty-three agents informed the interviewer that infant restraint systems were not supplied by the airline. One agent was unsure and another indicated that the airline would provide the seats on a fee rental basis. All forty-five agents assured the interviewer that passengers were free to bring their own infant restraint systems on board the aircraft. No agents mentioned that the seats had to be FAA approved. 
Table 3

Additional Survey Results of Airline Reservation Agents

\begin{tabular}{|c|c|c|c|c|}
\hline Airline & $\begin{array}{l}\text { Is Free Seat } \\
\text { Assigned W/O } \\
\text { Ticket? }\end{array}$ & $\begin{array}{l}\text { Will Adult Seat } \\
\text { Belt Protect } \\
\text { Child? }\end{array}$ & $\begin{array}{c}\text { Can Parent } \\
\text { Bring Own } \\
\text { Seat? }\end{array}$ & $\begin{array}{c}\text { Does Child Seat } \\
\text { Count as Carry } \\
\text { On? }\end{array}$ \\
\hline American & $\begin{array}{l}\text { Yes: } 5 \\
\text { No: } 0\end{array}$ & $\begin{array}{l}\text { Yes: } 5 \\
\text { No: } 0\end{array}$ & $\begin{array}{l}\text { Yes: } 5 \\
\text { No: } 0\end{array}$ & $\begin{array}{l}\text { Yes: } 3 \\
\text { No: } 2\end{array}$ \\
\hline America West & $\begin{array}{l}\text { Yes: } 5 \\
\text { No: } 0\end{array}$ & $\begin{array}{l}\text { Yes: } 5 \\
\text { No: } 0\end{array}$ & $\begin{array}{l}\text { Yes: } 5 \\
\text { No: } 0\end{array}$ & $\begin{array}{l}\text { Yes: } 4 \\
\text { No: } 1\end{array}$ \\
\hline Continental & $\begin{array}{l}\text { Yes: } 5 \\
\text { No: } 0\end{array}$ & $\begin{array}{l}\text { Yes: } 5 \\
\text { No: } 0\end{array}$ & $\begin{array}{l}\text { Yes: } 5 \\
\text { No: } 0\end{array}$ & $\begin{array}{l}\text { Yes: } 4 \\
\text { No: } 1\end{array}$ \\
\hline Delta & $\begin{array}{l}\text { Yes: } 5 \\
\text { No: } 0\end{array}$ & $\begin{array}{l}\text { Yes: } 5 \\
\text { No: } 0\end{array}$ & $\begin{array}{l}\text { Yes: } 5 \\
\text { No: } 0\end{array}$ & $\begin{array}{l}\text { Yes: } 5 \\
\text { No: } 0\end{array}$ \\
\hline Northwest & $\begin{array}{l}\text { Yes: } 5 \\
\text { No: } 0\end{array}$ & $\begin{array}{l}\text { Yes: } 5 \\
\text { No: } 0\end{array}$ & $\begin{array}{l}\text { Yes: } 5 \\
\text { No: } 0\end{array}$ & $\begin{array}{l}\text { Yes: } 5 \\
\text { No: } 0\end{array}$ \\
\hline Southwest & $\begin{array}{l}\text { Yes: } 5 \\
\text { No: } 0\end{array}$ & $\begin{array}{l}\text { Yes: } 5 \\
\text { No: } 0\end{array}$ & $\begin{array}{l}\text { Yes: } 5 \\
\text { No: } 0\end{array}$ & $\begin{array}{l}\text { Yes: } 5 \\
\text { No: } 0\end{array}$ \\
\hline TWA & $\begin{array}{l}\text { Yes: } 5 \\
\text { No: } 0\end{array}$ & $\begin{array}{l}\text { Yes: } 5 \\
\text { No: } 0\end{array}$ & $\begin{array}{l}\text { Yes: } 5 \\
\text { No: } 0\end{array}$ & $\begin{array}{l}\text { Yes: } 5 \\
\text { No: } 0\end{array}$ \\
\hline United & $\begin{array}{l}\text { Yes: } 5 \\
\text { No: } 0\end{array}$ & $\begin{array}{l}\text { Yes: } 5 \\
\text { No: } 0\end{array}$ & $\begin{array}{l}\text { Yes: } 4 \\
\text { No: } 1\end{array}$ & $\begin{array}{l}\text { Yes: } 3 \\
\text { No: } 2\end{array}$ \\
\hline USAir & $\begin{array}{l}\text { Yes: } 5 \\
\text { No: } 0\end{array}$ & $\begin{array}{l}\text { Yes: } 5 \\
\text { No: } 0\end{array}$ & $\begin{array}{l}\text { Yes: } 5 \\
\text { No: } 0\end{array}$ & $\begin{array}{l}\text { Yes: } 5 \\
\text { No: } 0\end{array}$ \\
\hline
\end{tabular}

To provide additional information to the traveling public questions were asked of the reservation agents by the interviewer in addition to those asked of management. The results of these additional questions are tabulated in Table 3 above. All of the agents responded that if the child were flying at no charge, it would not be possible to specifically assign a seat to that child. All agents assured the interviewer that if the infant had a separate seat on the aircraft, the adult seat belts would be adequate restraint protection for the infant.

If a passenger were to bring a car seat along for a non-paying infant, thirty-nine agents were of the opinion that the car seat would count against the paying passenger's carry-on allowance. Six agents indicated that their airline would not count the infant restraint system against the allowance. These six agents represented five different airlines (see Table 3).

\section{Interpretation of Survey Results}

It appears from the survey results that, in general, management's policies regarding airline travel by infants have been effectively communicated to the reservation agents. It is clear that infants can fly free on all of the nine airlines and all of the airlines allow the parents 
to bring an infant seat on board the aircraft although airline management differed from the agents on the exact requirements of the infant seat.

The airlines differed from each other on policies covering the use of infant restraint systems and how to interpret those policies. In many areas, reservation agents either did not understand management policies or did not convey such policies to the customer. The most significant area of confusion or disagreement between management and the reservation agents was in the area of emergency procedures. It must be acknowledged, of course, that airline reservation agents are not trained in aircraft emergency procedures. Thus, their lack of knowledge in this area is understandable. However, management, being aware of that lack of knowledge by the reservation agents, should discourage the agents from making any authoritative response to customers who inquire about such procedures unless the agents are first given additional training in that area.

\section{Recommendations}

United States airline management personnel need to continually educate and inform their reservations agents regarding the policies of their airlines in the use of infant restraint systems. In the education of the reservations agents airline management personnel need to place more emphasis on the FAA requirements controlling use of the infant restraint systems on board commercial aircraft. Members of the public traveling with infants need to be properly informed of airline policy and FAA requirements when they call to make reservations for travel on commercial aircraft with their small children. A resolution needs to be reached regarding the two different approaches to the problem of restraining infants on airplanes: education regarding the use of infant restraint systems or mandating the use of such systems, as was discussed in the section of this research article entitled Background Literature. Infant lives would undoubtedly be saved if the airlines and the FAA combined now to jointly cooperate on an intensive effort to educate the traveling public regarding the use of infant restraint systems on commercial aircraft.

One solution to this dilemma, for the short term, is for all of the airlines to cooperate in the development of a policy, consistent among all of the airlines, which guides the reservations agents and the flight attendants regarding the carriage of infants on commercial airliners. Airlines can capitalize on the desire of families to travel as a unit by advertising themselves as "family friendly" airlines. Airlines could also follow the lead of the automotive industry and include in the refurbishment of existing airplanes, or in the design of new airplanes, special child seats such as are installed in some of the new automobiles.

Whatever approach to the use of infant restraint systems is finally adopted, it should be accomplished before more infant lives are lost. If the use of infant restraint systems is not mandated, then both the FAA and the airlines should educate the public regarding the use of infant seats, and the parents of infants should be strongly encouraged to always use infant restraint systems for their small children who are traveling by air. Additional research should be accomplished and surveys should be conducted to determine if a significant education program implemented by the FAA and by the airlines would result in an increase in the voluntary purchase of additional airline seats and the use of infant restraint systems by parents traveling with their infant children. 


\section{References}

Alreck, P. \& Settle, R. (1985). The survey research handbook. Homewood, IL: Irwin. Child restraint systems on aircraft (1990). A bill to amend the Federal Aviation Act of 1958 to require the use of child safety restraint systems approved by the Secretary of Transportation on commercial aircraft. Hearing before the Subcommittee on Aviation of the House Committee on Public Works and Transportation, (101st Cong., 2nd Sess. 79 - testimony of Jan Brown).

Congress. House of Representatives. (1995). A bill to amend Title 49, United States Code, to require the use of child safety restraint systems approved by the Secretary of Transportation on commercial aircraft. (104th Cong., 1st sess., H.R. 1309). Washington, DC: U.S. Government Printing Office.

Federal Aviation Administration. (1996). Volume 61, Federal Register, page 28416.

Field, D. (1996, May 29) Child-seat stalemate; FAA refuses to mandate safety devices on airliners. The Washington Times, p. B7.

Gowdy, V., \& DeWeese, R. (1994). The performance of child restraint devices in transport airplane passenger seats, DOT/FAA/AAM-94/19, Oklahoma City, OK: Civil Aeromedical Institute, Federal Aviation Administration,1, 12, 27-28.

1995 Information For Public Affairs, Inc., (1996, August 6) Bill Number H. R. 1309.

104th Cong., 1st Sess. LEXIS. Library: LEGIS. File: BLCAST.

Lightfoot, J. (1996, July 8). Lightfoot announces hearing on FAA child safety seat policy. Congressional Press Releases. Washington, DC: Federal Document Clearing House.

National Transportation Safety Board (1990). Aircraft accident report, United Airines

Flight 232, Sioux Gateway Airport, Sioux City, lowa, July 19, 1989 (PB 90-9104060 NTSB/AAR-90/06), 21-23, 40, 75, 77. Washington, DC: U.S. Government Printing Office.

Simon, J. \& Burstein, P. (1985). Basic Research Methods in Social Science, 3rd ed. New York: Random House.

Spencer, P. (1994, March). Consumers Research Magazine, 77/3, 43.

The FAA: Too slow to act on ailline safety? (1995, June). Consumer Reports, 60, 385.

Title 14, Code of Federal Regulations, Sections 121.311, 121.311(b) and 121.311(c) (1995), Federal aviation regulations. Washington D.C. United States Government Printing Office.

U.S. Department of Transportation, National Highway Traffic Safety Administration (1993). Child passenger safety resource manual, 115.

Windle, R. J., \& Dresner, M. E. (1991). Mandatory child safety seats in air transport: Do they save lives? Journal of the Transportation Research Forum, 31(2), 309-316. 